\title{
Article
}

\section{White Brined Cheese Production by Incorporation of a Traditional Milk-Cereal Prebiotic Matrix with a Candidate Probiotic Bacterial Strain}

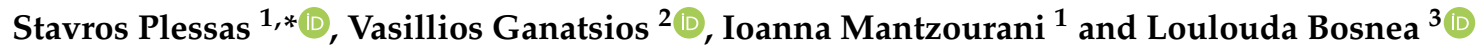 \\ 1 Laboratory of Food Processing, Department of Agriculture Development, Democritus University of Thrace, \\ 68200 Orestiada, Greece; imantzou@agro.duth.gr \\ 2 Department of Agricultural Biotechnology and Oenology, International Hellenic University, \\ 66100 Drama, Greece; v.gkanatsios@gmail.com \\ 3 Dairy Research Department, Institute of Technology of Agricultural Products, Hellenic Agricultural \\ Organization ‘DIMITRA', Katsikas, 45221 Ioannina, Greece; louloudabosnea@gmail.com \\ * Correspondence: splessas@agro.duth.gr; Tel.: +30-2552041141; Fax: +30-255204141
}

check for

updates

Citation: Plessas, S.; Ganatsios, V.; Mantzourani, I.; Bosnea, L. White Brined Cheese Production by Incorporation of a Traditional Milk-Cereal Prebiotic Matrix with a Candidate Probiotic Bacterial Strain. Appl. Sci. 2021, 11, 6182. https:// doi.org/10.3390/app11136182

Academic Editor:

Alessandra Biancolillo

Received: 8 June 2021

Accepted: 30 June 2021

Published: 3 July 2021

Publisher's Note: MDPI stays neutral with regard to jurisdictional claims in published maps and institutional affiliations.

Copyright: (c) 2021 by the authors. Licensee MDPI, Basel, Switzerland. This article is an open access article distributed under the terms and conditions of the Creative Commons Attribution (CC BY) license (https:// creativecommons.org/licenses/by/ $4.0 /)$.
Featured Application: Novel functional dairy product.

\begin{abstract}
The aim of the present study is the evaluation of a novel potentially probiotic Lactobacillus paracasei SP5, previously isolated from dairy products, as a starter culture of white brined cheese production, either free or immobilized on a traditional food, "trahanas", in order to provide protection to the starter culture and a prebiotic effect. All produced cheeses were compared with cheese manufactured by renin enzyme. Several parameters that affect the acceptability, quality, and shelf life of white brined cheese were investigated, including microbial populations, physicochemical characteristics, and cheese volatiles through 70 days of ripening and storage. White brined cheese production by free or immobilized L. paracasei SP5 resulted in significantly higher acidity (over $0.8 \mathrm{~g}$ of lactic acid/100 $\mathrm{g}$ of cheese at the 70th day of ripening) and significantly reduced counts (around $50 \%$ ) of coliforms, yeasts, and fungi compared to cheese produced with no starter culture. The use of the freeze-dried novel starter culture, either free or immobilized, improved the aromatic profile of cheeses as was proven through a GC-MS analysis. In addition, it should be underlined that the application of the novel strain led to white brined cheese with improved overall quality and sensory characteristics. The results indicate the potential industrial use of freeze-dried L. paracasei SP5 as a starter culture for the production of good-quality functional white brined cheeses.
\end{abstract}

Keywords: white brined cheese; cheese quality; ripening; prebiotic; probiotic; aromatic profile

\section{Introduction}

While the consumption of foods is intended for delivering required nutrients, a new trend has been developed lately regarding the development of functional foods with additional properties contributing positively in health [1-3]. Likewise, there is an increased demand and preference by the consumers lately to functional foods. The main reasons for this new trend are the many advantages that functional foods may offer to the consumers, such as an enhancement of the immune system, improvements of the gastrointestinal system, and the prevention of various diseases and disorders (e.g., lactose intolerance, gluten intolerance, diabetes, and hypercholesterolemia) [2,4-6]. There are many subcategories of functional foods such as prebiotic and probiotics. Probiotics are usually fermented food products containing at the final product probiotic microorganisms in adequate amounts [2,7]. Probiotic microorganisms are nonpathogenic living microorganisms employed in foods for the delivery of health benefits on the host [2,4]. Various probiotic microbial strains have been isolated from fermented food products [2,8-13]. The 
required viability levels of the probiotic bacterial strains should be at least $10^{6} \mathrm{CFU} / \mathrm{g}$ or $\mathrm{ml}$ throughout storage in order to deliver a probiotic effect in products $[2,7]$.

Besides delivery of health claims, other factors such as sensorial features, consumers acceptability, consumers diet habits, costs, and the preservation and sustainability of functional foods should be taken into account for the successful commercialization of each product [14-16]. In addition, the level of knowledge of the consumers towards the potential health benefits and nutritional issues of functional foods is also being taken into account. Thus, traditional fermented products seem to be a safe strategic choice for the development of these products, due to the fact that they are familiar to the consumers $[2,7,17]$. In this manner, popular dairy products, such as cheese, acid milk, and yogurt, have examined and eventually commercialized [18-22]. More specific, many scientific efforts have been conducted regarding the production of fermented probiotic cheese [20,22-25]. Cheese matrix provides significant advantages as probiotic carrier as it includes fat content, buffering capacity, lactose as fermentable sugar, and high density; these are some of the reasons that encourage the survival of probiotic strains during storage and through the passage of the gastrointestinal tract [2,25]. In addition, cheese is considered as a worldwide consumed product with high acceptance by the consumers [26]. Specifically, white brined cheeses are the most popular types of cheeses produced in the Northeastern Mediterranean area $[7,27,28]$. They are usually dry-salted and then matured and stored in brine $[20,28]$. The industrial interest for white brined cheeses production has been boosted lately, leading to the production of high quantities in large dairies. The main constituents of white brined cheeses are (i) pasteurized bovine and/or mixed milks and (ii) a starter culture [28]. However, the selection of proper probiotic microorganisms (starter or nonstarter culture) for the production of probiotic cheese is crucial [25]. As a result, various novel functional microorganisms have been examined and employed for the production of probiotic cheese with potential health benefits, advanced sensorial characteristics (flavor, aroma, texture), shelf extension, and advanced nutritional benefits [24,29-32]. In particular, the Lactobacillus species and emended genus are the most frequently employed probiotics, and they are considered the most proper for inclusion in food formulations because they are found naturally in a high variety of fermented foods $[2,33]$.

Viability of probiotic strains can be significantly influenced by the presence of high salt content in white brined cheeses, the presence of various antimicrobial agents produced by cheese starters, and lower $\mathrm{pH}$ value of the final cheese product $[23,25]$. Encapsulation and immobilization of probiotic strains are two common applied methods, in order to enhance the viability of probiotic strains in food matrices and afterwards in gastrointestinal environment $[2,29,34]$. Another pathway that was proven to be the most significant for the amelioration of probiotic viability is the application of an immobilization carrier providing prebiotic properties. Likewise, recent studies have shown that prebiotics can enhance probiotic viability through storage and can sustain cell viability in simulated gastrointestinal conditions, compared to free probiotic cells $[35,36]$. In this same view, the traditional Greek fermented food "trahanas", which is produced from cereals (wheat), has been successfully applied as immobilization support for food production [37], as cereals that contain nondigestible carbohydrates exert prebiotic properties [38].

Therefore, the present study aims to evaluate the technological properties of a novel candidate probiotic strain, Lactobacillus paracasei SP5, when used in white brined cheese production, applied as a free cell culture and immobilized in trahanas cereal-milk fermented food [37]. This strain is of particular interest as it was recently isolated from kefir grains with potential probiotic properties [8]. 


\section{Materials and Methods}

\subsection{Probiotic Strain}

The novel potential probiotic strain L. paracasei SP5 recently isolated from kefir grains was applied as a starter culture for white brined cheese production [20]. The biomass of $L$. paracasei SP5 was harvested by centrifugation at $5000 \mathrm{rpm}$ for $10 \mathrm{~min}$ at $25^{\circ} \mathrm{C}$ (Sigma 3K12, Bioblock Scientific, Saint Nom, France) after incubation in de Man-Rogosa-Sharpe (MRS) liquid broth (Fluka, Buchs, Switzerland) for $48 \mathrm{~h}\left(37^{\circ} \mathrm{C}\right)$. All media were sterilized prior to use by autoclave at $120^{\circ} \mathrm{C}$ for $15 \mathrm{~min}(1-1.5 \mathrm{~atm})$.

\subsection{Cell Immobilization}

Greek cereal-milk fermented food trahanas (TR) was applied as immobilization support of L. paracasei cells. The support was prepared by the procedure described previously [37]. For cell immobilization, L. paracasei SP5 mass were harvested with $5 \mathrm{~g}$ of TR respectively, in $500 \mathrm{~mL}$ MRS broth and incubated at $37{ }^{\circ} \mathrm{C}$ for $48 \mathrm{~h}$. Subsequently, the immobilized cells were washed twice with Ringer's solution at $0.25 \%$ strength for the removal of free cells [35].

\subsection{Freeze Drying}

Immobilized cells of $L$. paracasei SP5 on TR were frozen to $-44{ }^{\circ} \mathrm{C}$ at a cooling rate of $5{ }^{\circ} \mathrm{C} \min ^{-1}$ and freeze-dried for $48 \mathrm{~h}$ at $5-15 \mathrm{mbar}$ and at $-45^{\circ} \mathrm{C}$ on a FreeZone 4.5 freezedrying system (Labconco, Ft. Scott, KS, Kansas, USA) [35]. Subsequently, they were applied in cheese production.

\subsection{Cheesemaking}

Standardized fresh sheep milk was pasteurized at $63^{\circ} \mathrm{C}$ for $30 \mathrm{~min}$ and then cooled to $35-37^{\circ} \mathrm{C}$. Calcium chloride solution $(0.2 \% w / v)$ was added to the cheese milk, and then the starter culture was added. More specifically, 3 cheeses were produced: (i) with no starter culture and with rennin enzyme (F), (ii) with free freeze-dried cells of L. paracasei SP5 (FFC), and (iii) with immobilized freeze-dried L. paracasei SP5 cells on TR (FITRC). The milk was held for $30 \mathrm{~min}$ at $35{ }^{\circ} \mathrm{C}$ for culture maturation. Afterwards, powdered rennet was added to achieve coagulation in about $50 \mathrm{~min}$ at $35^{\circ} \mathrm{C}$. After coagulation, the curd was cut into cubes of $2 \mathrm{~cm}$ and left to rest for $10 \mathrm{~min}$. The sliced curd was then transferred into molds, stored at $18{ }^{\circ} \mathrm{C}$ and turned every hour for $3 \mathrm{~h}$ for whey drainage, surface salted using dry salt, and then left overnight to complete whey drainage. Following this, the cheeses were placed in containers with brine $(12 \%)$ and kept at $18{ }^{\circ} \mathrm{C}$ for approximately 15 days for cheese ripening. Subsequently, the cheese was sealed at $\mathrm{pH} 4.6$ and stored at $4{ }^{\circ} \mathrm{C}$ [20]. Samples were collected at various intervals of production, ripening, and storage and subjected to physicochemical analyses. All treatments were carried out in triplicate, and the mean values are presented.

\subsection{Physicochemical Analysis}

Cheese samples (20 g each) were macerated with warm water $\left(40{ }^{\circ} \mathrm{C}\right)$ to a total volume of $210 \mathrm{~mL}$. After filtration of each sample, the filtrate was used for lactic acid, ethanol, and residual sugar determination. Moisture content, ash content, and acidity (expressed as lactic acid) of cheese samples [20]. Total nitrogen in dry matter (DM) was determined using the Kjeldahl procedure. Residual sugar (lactose, glucose, and galactose) and ethanol were determined by high performance liquid chromatography (HPLC) analyses carried out in triplicate, and the mean data are presented. (Table 1). 
Table 1. Effect of L. paracasei SP5 on physicochemical characteristics and sensory attributes of white brined cheese.

\begin{tabular}{|c|c|c|c|c|c|c|c|c|c|}
\hline $\begin{array}{l}\text { Cheese } \\
\text { Sample }\end{array}$ & $\begin{array}{l}\text { Ripening } \\
\text { Period } \\
\text { (Days) }\end{array}$ & $\begin{array}{l}\text { Lactose } \\
\text { (g/100 g of } \\
\text { Cheese) }\end{array}$ & $\begin{array}{l}\text { Glucose } \\
\text { (g/100 g of } \\
\text { Cheese) }\end{array}$ & $\begin{array}{l}\text { Galactose } \\
\text { (g/100 g of } \\
\text { Cheese) }\end{array}$ & $\begin{array}{l}\text { Ethanol } \\
\text { (g/100 g of } \\
\text { Cheese) }\end{array}$ & $\mathrm{pH}$ & $\begin{array}{c}\text { Acidity } \\
\text { (g of Lactic } \\
\text { Acid/100 g } \\
\text { of Cheese) }\end{array}$ & $\begin{array}{c}\text { Moisture } \\
(\%, w t / w t)\end{array}$ & $\begin{array}{l}\text { Total N in } \\
\text { DM (\%) }\end{array}$ \\
\hline \multirow{5}{*}{ F } & 0 & $3.70 \pm 0.05^{\mathrm{a}}$ & $0.26 \pm 0.04^{\mathrm{a}}$ & $0.28 \pm 0.05^{\mathrm{a}}$ & $0.05 \pm 0.02^{b}$ & $6.49 \pm 0.10^{\mathrm{a}}$ & $0.08 \pm 0.01^{b}$ & $58.5 \pm 1.1^{\mathrm{a}}$ & \\
\hline & 1 & $3.74 \pm 0.05^{\mathrm{a}}$ & $0.12 \pm 0.06^{b}$ & $0.14 \pm 0.04^{b}$ & $0.05 \pm 0.01^{b}$ & $6.43 \pm 0.08^{a}$ & $0.11 \pm 0.02^{b}$ & $54.3 \pm 1.9^{a}$ & \\
\hline & 14 & $2.26 \pm 0.13^{b}$ & $\operatorname{Tr}$ & $\operatorname{Tr}$ & $0.11 \pm 0.02^{\mathrm{a}}$ & $5.49 \pm 0.11^{b}$ & $0.39 \pm 0.05^{\mathrm{a}}$ & $55.2 \pm 2.4^{\mathrm{a}}$ & \\
\hline & 42 & $1.39 \pm 0.12^{c}$ & $\operatorname{Tr}$ & $\operatorname{Tr}$ & $0.10 \pm 0.02^{\mathrm{a}}$ & $5.50 \pm 0.10^{b}$ & $0.33 \pm 0.05^{\mathrm{a}}$ & $52.7 \pm 2.3^{\mathrm{a}}$ & \\
\hline & 70 & $0.95 \pm 0.11^{\mathrm{ad}}$ & $\operatorname{Tr}$ & $\operatorname{Tr}$ & $0.09 \pm 0.02^{\mathrm{a}}$ & $5.40 \pm 0.10^{b}$ & $0.28 \pm 0.07^{\mathrm{a}}$ & $53.7 \pm 3.1^{\mathrm{a}}$ & $4.59 \pm 0.15^{c}$ \\
\hline \multirow{5}{*}{ FFC } & 0 & $2.89 \pm 0.10^{\mathrm{a}}$ & $0.24 \pm 0.05^{\mathrm{a}}$ & $0.29 \pm 0.05^{\mathrm{a}}$ & $0.03 \pm 0.01^{\mathrm{a}}$ & $6.29 \pm 0.10^{\mathrm{a}}$ & $0.08 \pm 0.04^{b}$ & $61.2 \pm 1.9^{a}$ & \\
\hline & 1 & $2.73 \pm 0.23 \mathrm{ab}$ & $0.12 \pm 0.02^{b}$ & $0.15 \pm 0.05^{b}$ & $0.04 \pm 0.01^{\mathrm{a}}$ & $5.33 \pm 0.11^{b}$ & $0.16 \pm 0.05^{b}$ & $51.3 \pm 1.5^{\mathrm{a}}$ & \\
\hline & 14 & $0.98 \pm 0.10^{c}$ & $\operatorname{Tr}$ & $\operatorname{Tr}$ & $0.05 \pm 0.02^{\mathrm{a}}$ & $4.84 \pm 0.10^{c}$ & $0.79 \pm 0.05^{\mathrm{a}}$ & $50.8 \pm 2.4^{\mathrm{a}}$ & \\
\hline & 42 & $0.34 \pm 0.08^{\mathrm{d}}$ & $\mathrm{Tr}$ & $\mathrm{Tr}$ & $0.07 \pm 0.02^{\mathrm{a}}$ & $4.57 \pm 0.10^{d}$ & $0.81 \pm 0.05^{\mathrm{a}}$ & $50.7 \pm 1.9^{\mathrm{a}}$ & \\
\hline & 70 & $0.19 \pm 0.05^{\mathrm{e}}$ & $\operatorname{Tr}$ & $\operatorname{Tr}$ & $0.05 \pm 0.01^{\mathrm{a}}$ & $4.50 \pm 0.08^{\mathrm{d}}$ & $0.84 \pm 0.07^{\mathrm{a}}$ & $50.5 \pm 2.1^{\mathrm{a}}$ & $5.36 \pm 0.18^{b}$ \\
\hline \multirow{5}{*}{ FITRC } & 0 & $2.87 \pm 0.11^{\mathrm{a}}$ & $0.31 \pm 0.05^{\mathrm{a}}$ & $0.24 \pm 0.03^{a}$ & $0.05 \pm 0.01^{\mathrm{a}}$ & $6.33 \pm 0.09^{a}$ & $0.18 \pm 0.05^{\mathrm{d}}$ & $59.4 \pm 2.5^{\mathrm{a}}$ & \\
\hline & 1 & $2.31 \pm 0.05^{b}$ & $0.10 \pm 0.04^{b}$ & $0.11 \pm 0.04^{b}$ & $0.05 \pm 0.01^{\mathrm{a}}$ & $5.45 \pm 0.07^{b}$ & $0.37 \pm 0.05^{c}$ & $52.3 \pm 2.1^{\mathrm{a}}$ & \\
\hline & 14 & $0.69 \pm 0.05^{c}$ & $\operatorname{Tr}$ & $\operatorname{Tr}$ & $0.08 \pm 0.02^{\mathrm{a}}$ & $4.95 \pm 0.12^{c}$ & $0.73 \pm 0.09^{b}$ & $50.4 \pm 1.5^{\mathrm{a}}$ & \\
\hline & 42 & $0.21 \pm 0.09^{b}$ & $\mathrm{Tr}$ & $\mathrm{Tr}$ & $0.09 \pm 0.03^{\mathrm{a}}$ & $4.75 \pm 0.08^{c}$ & $0.99 \pm 0.08^{\mathrm{a}}$ & $51.0 \pm 3.2^{\mathrm{a}}$ & \\
\hline & 70 & $\operatorname{Tr}$ & $\operatorname{Tr}$ & $\operatorname{Tr}$ & $0.05 \pm 0.01^{\mathrm{a}}$ & $4.34 \pm 0.11^{\mathrm{d}}$ & $1.03 \pm 0.07^{\mathrm{a}}$ & $50.4 \pm 3.3^{\mathrm{a}}$ & $5.88 \pm 0.07^{a}$ \\
\hline
\end{tabular}

Different superscript letters in a column indicates statistically significant differences (ANOVA, Tukey's HSD multiple range test, $p<0.05$ ); $\mathrm{Tr}=$ trace; F = white brined cheese with no starter culture; FFC = white brined cheese produced with free $L$. paracasei SP5; FITRC = white brined cheese produced with immobilized L. paracasei SP5 on trahanas.

\subsection{Solid-Phase Microextraction GC-MS Analysis}

Volatile compounds of cheese samples after 70 days from production were determined through solid-phase microextraction (SPME) GC-MS analysis. The procedure was the same as described previously [24]. Each determination was carried out in triplicate, and the mean data are presented.

\subsection{Microbiological Analyses}

A microbiological analysis of cheese samples was carried out, aiming at the determination of total aerobic count, lactococci, lactobacilli, yeasts and fungi, and coliforms levels. The procedure followed was the same as described previously [23].

\subsection{Preliminary Sensory Evaluation}

Sensory evaluation of Feta-type cheese was conducted to evaluate the influence of immobilized $L$. paracasei SP5 on cheese preliminary sensory characteristics. Sensory evaluation was carried out by 20 laboratory members, priory trained, using locally-approved protocols [37]. Cheese samples were evaluated at the 70th day of storage regarding overall acceptability. The participated laboratory members were between 25 and 50 years old and were frequent consumers of white brined cheese (more than once a week). The results are based on a $0-10$ preference scale and are presented as a star chart of the product's attributes [29].

\subsection{Experimental Design and Statistical Analysis}

All experiments were carried out in triplicate. Significance was established at $p<0.05$. Results were analyzed for statistical significance with ANOVA, and Duncan's multiple range test was used to determine significant differences among results; coefficients, ANOVA tables, and significance $(p<0.05)$ were computed using Statistica version 5.0 (StatSoft Inc., Tulsa, OK, USA).

\section{Results and Discussion}

\subsection{Physicochemical Characteristics of White Brined Cheeses}

According to Table 1, sugar content (lactose, glucose and galactose), ethanol, acidity, $\mathrm{pH}$, and moisture were significantly affected $(p<0.05)$. During the ripening period of the cheeses, the acidity was increased, while $\mathrm{pH}$ and moisture significantly decreased $(p<0.05)$. The $\mathrm{pH}$ value and acidity of cheese samples were significantly affected by the ripening time and the type of the starter culture that was used for the production of the cheeses. The 
control cheese retained the $\mathrm{pH}$ in high levels, which is not appropriate for white brined cheeses; however, the cheeses with L. paracasei in free and immobilized form had levels of $\mathrm{pH}$ and acidity closer to similar traditional cheeses [35,39]. During the ripening period, the breakdown of proteins to nitrogen compounds by the proteolytic enzymes resulted in an increase of the proteolysis index and $\mathrm{pH}$ and decrease of the acidity. However, no starter culture was added to control cheeses; subsequently, the proteolysis was reduced, and the production of acidity as well as the consumption of sugars were significantly different from those of FFC and FITRC cheeses, which is in accordance with previous studies [40]. The breakdown of lipids to free fatty acids by the lipolytic enzymes led to the increase of the lipolysis index and the catabolism of lactose to lactic acid by the starter culture and total bacterial count. Moreover, the starter culture, whether free or immobilized, led to increased acidity and decreased $\mathrm{pH}$ levels of the final products as expected [20,24].

\subsection{Microbiological Analysis of White Brined Cheeses}

White brined cheeses are popular semi-soft or semi-hard cheeses and are consumed in many countries of the Mediterranean $[7,41]$. Specifically, Feta cheese is the main exploitation cheese of Greece and belong to white brined cheeses while it is produced from pasteurized milk to ensure the safety of consumers [7]. Several studies have focused on the production of brined cheese from pasteurized milk using different starter cultures, additives, different sources of milk, and changes in process conditions to stimulate the flavor and texture $[20,23,35]$. The commercial cheese bioprocess production of white brined cheese includes the addition of yogurt culture (S. thermophilus and Lactobacillus delbrueckii subsp. bulgaricus), providing cheese products with similar characteristics. The LAB in cheese products is typically elevated, which in turn increases the acidity at the beginning of the ripening process; when cheese is stored at $4{ }^{\circ} \mathrm{C}$, the count of LAB becomes constant for approximately 60 days [20,42]. On the other hand, mesophilic starter cultures may decrease during the prematuration period of cheese, especially in the existence of higher salt content $(6-8 \%)$ and $\mathrm{pH}$ of $<5.0$ [42]. Therefore, thermophilic and probiotic bacteria can be successfully applied as adjunct or starter cultures to enhance the flavor of brined cheese products.

In the present study, the population of lactococci was determined between 5.21 to $5.71 \log \mathrm{CFU} / \mathrm{g}$ in all produced cheeses at the beginning of the production and reached $6.39 \log \mathrm{CFU} / \mathrm{g}$ in the control cheese, where no starter culture was added at the end of the maturation period. In the two cheeses produced with the addition of freeze-dried $L$. paracasei SP5, the population of lactococci was around 5.2 to $5.8 \log \mathrm{CFU} / \mathrm{g}$ at the end of storage. As far as the lactobacillus is concerned, the population in control cheeses was from $6.1 \log \mathrm{CFU} / \mathrm{g}$ to $6.86 \log \mathrm{CFU} / \mathrm{g}$ at the end of storage. However, the population of lactobacilli in FFC and FITRC was elevated by $1.5 \log \mathrm{CFU} / \mathrm{g}$, when freeze-dried $L$. paracasei was added in free and immobilized form. This may be due to the immobilization support applied (i.e., trahanas), which may have exhibited prebiotic effects [35,37,38]. Over the years, it is evident that the addition of probiotic strains in cheeses may improve their functionality. Cheeses are considered to be a high-quality probiotic carrier because of their favorable environment (dense matrix, fat content, lower acidity than yogurt) and their buffering effect against the high acidic environment of the gastrointestinal track. Researchers [22-24,29] have previously tried to incorporate probiotic strains and prebiotics in cheeses, in order to produce cheeses with potential health benefits. Along this concept, our produced cheeses potentially have two distinct advantages: (i) the addition of a potential probiotic strain L. paracasei SP5 and (ii) the inclusion within the cheese matrix of a known cereal-based product with prebiotic properties. Therefore, the produced cheese could be considered of improved quality as it could lead to the development of novel functional dairy products with health-promoting properties.

The yeasts were at levels ranging from 4.3 to 5.12 for F, from 5.03 to $4.99 \log \mathrm{CFU} / \mathrm{g}$ for FFC, and from 5.17 to $3.71 \log$ CFU/g for FITRC, with fluctuations during storage. Yeasts are generally recognized as contaminants in the production of cheeses and white 
brined cheeses [20,43]. Although their spoilage potential varies for both species and strain levels, yeasts do present a microbiological hazard and thus can affect cheese quality in case of excessive growth. Such quality defects caused by yeasts in white brined cheese are mainly linked to enzymatic activities and metabolism of fermentable carbohydrates, leading to the production of metabolites $\left(\mathrm{CO}_{2}\right.$, fatty acids, volatile compounds, amino acids, sulfur compounds, etc.) and resulting in off-flavors, texture softening, discoloration, and swelling of cheese packages. The proliferation of spoilage yeast depends on maturation and storage conditions at each specific dairy, product characteristics, nutrients availability, and interactions with the coexisting microorganisms [44]. Manolopoulou analyzed Feta-brined cheese from three dairies in Southern Greece and found that the total yeast counts in curd varied between the dairies at 2-3 $\log \mathrm{CFU} / \mathrm{g}$ and generally increased during the ripening period at 3.41-4.66 log CFU/g [44]. In addition, another research group reported that yeasts are the predominant microorganisms in fresh brined cheese produced with nonpasteurized ewe's milk [45]. As a result, yeasts are mostly expected to occur during white brined cheese ripening. In the current study, the total yeast counts were highest after the fourth day of ripening at approximately $5.86 \log \mathrm{CFU} / \mathrm{g}$ and decreased after 60 days of ripening to $4.7 \log$ CFU/g. In Teleme, which is another traditional Greek white brined cheese and is currently produced on an industrial scale using yogurt commercial starters, the total counts of yeasts were determined to be up to $3.9 \mathrm{log} \mathrm{CFU} / \mathrm{g}$ [46]. In addition, yeasts are important in low levels for brined cheeses, as they are responsible for the flavor, given that they have the ability to convert milk proteins and fat into amino acids and free fatty acids (FFA), which are the precursors of aroma and flavor compounds [35,47-49].

On the other hand, coliforms are microorganisms that are undesirable in cheeses, and they usually are severely reduced during cheese ripening. Likewise, white brined cheese ripening may last up to 60 days, mainly depending on initial milk microflora and fermentation conditions $[7,41,50]$. In the current study, there was a significant reduction in coliform populations in both cheeses, where the starter culture was added approximately at $50 \%$ (around $2 \log \mathrm{CFU} / \mathrm{g}$ ) compared to the control samples, in which there was no starter culture, (Table 2). As a result, the starter culture, whether applied free or immobilized in trahanas, significantly affected the coliform population of cheese.

Table 2. Effect of L. paracasei SP5 on major microbial groups of white brined cheese.

\begin{tabular}{|c|c|c|c|c|c|c|}
\hline $\begin{array}{l}\text { Cheese } \\
\text { Sample }\end{array}$ & $\begin{array}{l}\text { Ripening and } \\
\text { Storage Period } \\
\text { (d) }\end{array}$ & $\begin{array}{c}\text { Total Aerobic } \\
\text { Count } \\
(\log \text { CFU/g) }\end{array}$ & $\begin{array}{c}\text { Lactococci } \\
(\log \text { CFU/g) }\end{array}$ & $\begin{array}{l}\text { Lactobacilli } \\
\text { (log CFU/g) }\end{array}$ & $\begin{array}{c}\text { Yeasts and } \\
\text { Fungi } \\
\text { (log CFU/g) }\end{array}$ & $\begin{array}{c}\text { Coliforms } \\
(\log \text { CFU/g) }\end{array}$ \\
\hline \multirow{5}{*}{$\mathrm{F}$} & 0 & $5.13 \pm 0.11^{c}$ & $5.21 \pm 0.13^{c}$ & $6.11 \pm 0.09^{d}$ & $4.31 \pm 0.23^{\mathrm{e}}$ & $4.49 \pm 0.23^{b}$ \\
\hline & 1 & $5.99 \pm 0.18^{b}$ & $6.56 \pm 0.21^{b}$ & $6.79 \pm 0.15^{c}$ & $5.83 \pm 0.11^{b}$ & $5.11 \pm 0.19^{a}$ \\
\hline & 14 & $8.89 \pm 0.15^{\mathrm{a}}$ & $7.23 \pm 0.17^{a}$ & $7.63 \pm 0.20^{b}$ & $6.47 \pm 0.08^{a}$ & $4.56 \pm 0.13^{b}$ \\
\hline & 42 & $7.99 \pm 0.30^{\mathrm{a}}$ & $6.49 \pm 0.13^{b}$ & $6.93 \pm 0.07^{\mathrm{a}}$ & $5.97 \pm 0.20^{b}$ & $4.48 \pm 0.19^{b}$ \\
\hline & 70 & $7.84 \pm 0.29^{a}$ & $6.39 \pm 0.22^{b}$ & $6.86 \pm 0.21^{\mathrm{a}}$ & $5.12 \pm 0.15^{d}$ & $3.78 \pm 0.16^{c}$ \\
\hline \multirow{5}{*}{ FFC } & 0 & $5.86 \pm 0.21^{c}$ & $5.34 \pm 0.24^{c}$ & $7.55 \pm 0.27^{c}$ & $5.03 \pm 0.31^{b}$ & $4.23 \pm 0.11^{b}$ \\
\hline & 1 & $6.99 \pm 0.17^{b}$ & $6.24 \pm 0.21^{\mathrm{a}}$ & $8.12 \pm 0.07^{b}$ & $6.23 \pm 0.20^{a}$ & $4.76 \pm 0.20^{a}$ \\
\hline & 14 & $8.66 \pm 0.19^{a}$ & $6.61 \pm 0.18^{a}$ & $8.71 \pm 0.18^{a}$ & $6.05 \pm 0.11^{a}$ & $4.00 \pm 0.14^{b}$ \\
\hline & 42 & $8.94 \pm 0.21^{\mathrm{a}}$ & $5.77 \pm 0.20^{b}$ & $8.79 \pm 0.15^{\mathrm{a}}$ & $4.85 \pm 0.21^{b}$ & $3.31 \pm 0.19^{\circ}$ \\
\hline & 70 & $8.77 \pm 0.19^{a}$ & $5.81 \pm 0.14^{b}$ & $8.61 \pm 0.21^{a}$ & $4.99 \pm 0.27^{b}$ & $2.14 \pm 0.08^{\mathrm{C}}$ \\
\hline \multirow{5}{*}{ FITRC } & 0 & $6.29 \pm 0.12^{c}$ & $5.71 \pm 0.15^{\mathrm{c}}$ & $7.63 \pm 0.11^{c}$ & $5.17 \pm 0.10^{b}$ & $4.05 \pm 0.19^{b}$ \\
\hline & 1 & $6.81 \pm 0.19^{b}$ & $6.36 \pm 0.28^{b}$ & $8.29 \pm 0.19^{c}$ & $6.35 \pm 0.23^{a}$ & $4.44 \pm 0.11^{a}$ \\
\hline & 14 & $9.02 \pm 0.17^{\mathrm{a}}$ & $6.98 \pm 0.21^{\mathrm{a}}$ & $9.33 \pm 0.22^{\mathrm{a}}$ & $6.05 \pm 0.17^{a}$ & $3.23 \pm 0.19^{\circ}$ \\
\hline & 42 & $8.89 \pm 0.11^{a}$ & $5.21 \pm 0.12^{d}$ & $8.83 \pm 0.13^{b}$ & $4.23 \pm 0.12^{c}$ & $2.67 \pm 0.29$ \\
\hline & 70 & $8.71 \pm 0.27^{\mathrm{a}}$ & $5.19 \pm 0.19^{d}$ & $8.83 \pm 0.21^{b}$ & $3.71 \pm 0.27^{d}$ & $1.89 \pm 0.12$ \\
\hline
\end{tabular}

Different superscript letters in a column indicates statistically significant differences (ANOVA, Tukey's HSD multiple range test, $p<0.05$ ). $\mathrm{F}=$ White brined cheese with no starter culture, FFC $=$ White brined cheese produced with free L. paracasei SP5, FITRC $=$ White brined cheese produced with immobilized L. paracasei SP5 on trahanas. 


\subsection{Aroma-Related Compounds}

The flavor of white brined cheeses is obtained during the metabolism activity of the bacteria on different components, including protein (proteolysis), lactose (fermentation), and fat (lipolysis). In our produced cheeses, a plethora of aroma-related compounds were detected (Tables 3 and 4). The carbonyl compounds identified included mainly aldehydes and ketones, and their concentrations were significantly higher in FFC and FTIRC samples than in F samples. 3-Methyl-butanal, present in F and FTIRC cheeses, can be derived from leucine and has a fruity aroma; octanal, identified in FTIRC cheese, and nonanal, present in all cheeses at similar levels, are described as having an aromatic note resembling fruits such as oranges. Benzaldehyde detected in all cases was described as having an odor of bitter almond, and it was higher in FTIRC cheeses. Lactones are generally characterized by fruity attributes, such as peach, apricot, and coconut, having a different detection threshold depending on the type of lactone. However, no $\gamma$-lactones were detected in our samples. The concentration of lactones was higher in FFC and FITRC samples compared with F cheese, revealing the positive effect on flavor formation (Table 4).

Table 3. Major aroma-related compounds $(\mu \mathrm{g} / \mathrm{kg}$ of cheese) detected in white brined cheeses during refrigerated storage (70th day of storage at $4^{\circ} \mathrm{C}$ ) by solid-phase microextraction (SPME) GC-MS technique.

\begin{tabular}{|c|c|c|c|c|c|}
\hline & Identification Methods & KI & $\mathbf{F}$ & FFC & FITRC \\
\hline \multicolumn{6}{|c|}{$\mu \mathrm{g} / \mathrm{kg}$} \\
\hline \multicolumn{6}{|l|}{ Esters } \\
\hline Ethyl butanoate & RT, KI, MS & 1041 & $1.03 \pm 0.10^{b}$ & $1.12 \pm 0.11^{b}$ & $1.43 \pm 0.10^{\mathrm{a}}$ \\
\hline Ethyl hexanoate & RT, KI, MS & 1251 & nd & $\mathrm{Nd}$ & $0.46 \pm 0.11$ \\
\hline Methyl octanoate & KI & 1380 & nd & $\mathrm{Nd}$ & $0.22 \pm 0.04$ \\
\hline Ethyl octanoate & RT, KI, MS & 1421 & nd & $\mathrm{Nd}$ & $0.13 \pm 0.03$ \\
\hline Ethyl decanoate & RT, KI, MS & 1652 & $8.73 \pm 0.11^{\mathrm{c}}$ & $9.55 \pm 0.11^{\mathrm{a}}$ & $9.17 \pm 0.11^{b}$ \\
\hline 2-Phenylethyl acetate & RT, KI, MS & 1830 & $1.21 \pm 0.04^{\mathrm{a}}$ & $1.22 \pm 0.06^{\mathrm{a}}$ & $1.11 \pm 0.03^{b}$ \\
\hline Ethyl dodecanoate & KI, MS & 1848 & $6.99 \pm 0.13^{b}$ & $6.49 \pm 0.24^{c}$ & $8.92 \pm 0.18^{a}$ \\
\hline $\begin{array}{c}\text { Ethyl hexadecanoate } \\
\text { Organic acids }\end{array}$ & KI, MS & 2248 & $1.01 \pm 0.19^{b}$ & $1.25 \pm 0.17^{\mathrm{b}}$ & $1.82 \pm 0.26^{\mathrm{a}}$ \\
\hline Butanoic acid & KI, MS & 1642 & $75.67 \pm 3.99^{b}$ & $93.23 \pm 3.39^{a}$ & $90.03 \pm 3.95^{\mathrm{a}}$ \\
\hline Hexanoic acid & KI, MS & 1851 & $119.27 \pm 3.95^{\mathrm{d}}$ & $132.9 \pm 3.22^{b}$ & $144.10 \pm 6.95^{\mathrm{a}}$ \\
\hline Octanoic acid & RT, KI, MS & 2064 & $69.76 \pm 4.25^{\mathrm{c}}$ & $67.32 \pm 3.34^{c}$ & $86.45 \pm 2.64^{\mathrm{a}}$ \\
\hline Nonanoic acid & RT, KI, MS & 2211 & $45.24 \pm 1.95^{c}$ & $55.2 \pm 2.09^{a}$ & $50.09 \pm 1.77^{b}$ \\
\hline Decanoic acid & RT, KI, MS & 2336 & $183.23 \pm 11.27^{\mathrm{a}}$ & $123.91 \pm 13.14^{\mathrm{c}}$ & $162.08 \pm 12.91^{b}$ \\
\hline $\begin{array}{c}\text { Dodecanoic acid } \\
\text { Alcohols }\end{array}$ & \multicolumn{5}{|c|}{ Alcohols } \\
\hline Ethanol & RT, KI, MS & 932 & $>10.000$ & $>10.000$ & $>10.000$ \\
\hline 3-Methyl-1-butanol & RT, KI, MS & 1216 & nd & $\mathrm{Nd}$ & 0.56 \\
\hline 1-Hexanol & RT, KI, MS & 1363 & $0.94 \pm 0.17^{\mathrm{a}}$ & $0.99 \pm 0.22^{\mathrm{a}}$ & $1.16 \pm 0.10^{\mathrm{a}}$ \\
\hline 1-Octen-3-ol & MS & 1457 & nd & $\mathrm{Nd}$ & nd \\
\hline 1-Octanol & $\mathrm{KI}, \mathrm{MS}$ & 1555 & nd & $\mathrm{Nd}$ & nd \\
\hline 1,3-Butanediol & KI, MS & 1576 & $0.99 \pm 0.10^{b}$ & $0.76 \pm 0.08^{c}$ & $1.29 \pm 0.06^{\mathrm{a}}$ \\
\hline Phenyl ethanol & RT, KI, MS & 1929 & $18.02 \pm 0.80^{b}$ & $17.06 \pm 1.99^{b}$ & $21.73 \pm 0.99^{\mathrm{a}}$ \\
\hline \multicolumn{6}{|l|}{ Carbonyl compounds } \\
\hline 3-Methyl-butanal & KI, MS & 953 & $0.17 \pm 0.04^{b}$ & $0.24 \pm 0.05^{b}$ & $0.37 \pm 0.03^{b}$ \\
\hline Hexanal & $\mathrm{KI}, \mathrm{MS}$ & 1088 & nd & $\mathrm{Nd}$ & nd \\
\hline Octanal & $\mathrm{KI}, \mathrm{MS}$ & 1301 & nd & $\mathrm{Nd}$ & 0.26 \\
\hline 3-Hydroxy-2-butanone & KI, MS & 1310 & nd & $\mathrm{Nd}$ & nd \\
\hline Nonanal & KI, MS & 1395 & $1.71 \pm 0.14^{\mathrm{a}}$ & $1.87 \pm 0.10^{\mathrm{a}}$ & $1.79 \pm 0.12^{\mathrm{a}}$ \\
\hline Benzaldehyde & $\mathrm{KI}, \mathrm{MS}$ & 1528 & $2.10 \pm 0.10^{b}$ & $1.95 \pm 0.18^{b}$ & $2.44 \pm 0.13^{\mathrm{a}}$ \\
\hline (E)-2-Nonenal & $\mathrm{KI}, \mathrm{MS}$ & 1557 & $0.95 \pm 0.07^{\mathrm{a}}$ & $0.87 \pm 0.08^{a}$ & $0.90 \pm 0.10^{a}$ \\
\hline
\end{tabular}


Table 3. Cont.

\begin{tabular}{cccccc}
\hline & Identification Methods & KI & F & FFC & FITRC \\
\hline Lactones & & & & & \\
$\gamma$-Decalactone & MS & 2189 & $1.22 \pm 0.10^{\mathrm{b}}$ & $1.30 \pm 0.10^{\mathrm{b}}$ & $1.62 \pm 0.14^{\mathrm{a}}$ \\
$\delta$-Decalactone & MS & 2209 & $1.01 \pm 0.08^{\mathrm{b}}$ & $1.19 \pm 0.10^{\mathrm{a}}$ & $1.37 \pm 0.16^{\mathrm{a}}$ \\
$\gamma$-Dodecalactone & MS & 2388 & nd & Nd & nd \\
$\delta$-Dodecalactone & MS & 2437 & $3.05 \pm 0.05^{\mathrm{b}}$ & $3.04 \pm 0.07^{\mathrm{b}}$ & $3.29 \pm 0.10^{\mathrm{a}}$ \\
\hline
\end{tabular}

Different superscript letters in a row indicates statistically significant differences (ANOVA, Tukey's HSD multiple range test, $p<0.05$ ), nd: not detected, $\mathrm{F}=$ white brined cheese with no starter culture; FFC = white brined cheese produced with free $L$. paracasei SP5; FITRC $=$ white brined cheese produced with immobilized L. paracasei SP5 on trahanas.

Table 4. Effect of free and immobilized L. paracasei SP5 on trahanas as starter culture on major aroma groups (mean values, $\mu \mathrm{g} / \mathrm{kg}$ of cheese) of white brined cheese after ripening for $70 \mathrm{~d}$ using the solid-phase microextraction (SPME) GC-MS technique.

\begin{tabular}{cccc}
\hline & F & FFC & FITRC \\
\hline Esters & & $\mu \mathrm{g} / \mathrm{kg}$ & \\
\hline Organic acids & 16.77 & 18.4 & 23.72 \\
Alcohols & 430.65 & 540.28 & 596.55 \\
Carbonyl compounds & 20.14 & 20.75 & 26.01 \\
Lactones & 4.92 & 4.73 & 5.63 \\
& 4.96 & 5.59 & 6.61
\end{tabular}

$\overline{\mathrm{F}}=$ white brined cheese with no starter culture; FFC = white brined cheese produced with free $L$. paracasei SP5; FITRC $=$ white brined cheese produced with immobilized L. paracasei SP5 on trahanas.

Yeasts, which also have the ability to convert milk proteins and fat into amino acids and free fatty acids (FFA), are the precursors of aroma and flavor compounds. In addition, ethanol, which is considered as a major byproduct of yeast metabolism, has a good impact in cheese flavor [46]. Specifically, a fruity flavor may be developed when ethanol reacts with short-chain fatty acids in order to form a variety of esters [35,51].

Several probiotic strains have been utilized recently in the manufacture of different cheese types as adjunct starter cultures, such as Bifidobacterium bifidum, Lacticaseibacillus casei, and Lactococcus lactis; this use is attributable to their metabolism activity in producing desirable flavors $[23,52-54]$. Furthermore, probiotic bacteria have been used to provide health benefits to the consumers when at least 6-7 log CFU/g exist in the product [2]. Probiotic cultures can possibly enhance the flavor and texture of cheese and help in the production of more favorable and unique cheeses. This is mainly because probiotic bacteria have higher metabolism to improve proteolysis (degrading of protein), which in turn can produce more flavor components. It was found that using adjunct cultures (such as LL) in making cheeses with $7 \%$ fat resulted in similar flavor and texture characteristics as compared to $22 \%$ fat Feta cheese [55].

Our results demonstrate the plethora of aroma compounds formed by the action of free and immobilized L. paracasei SP5 (Table 4). However, it is difficult to interpret the relationship between the microbial associations and the chemical compounds, due to the complexity of microbial interactions, and thus it is yet unknown how this relationship is formed.

\subsection{Preliminary Sensory Evaluation}

The cheese samples produced using free or immobilized L. paracasei starter cultures were compared with white brined cheese produced with no starter culture in regard to their sensory characteristics. White brined cheeses produced with immobilized or free $L$. paracasei SP5 scored significantly $(p<0.05)$ higher values compared with cheese produced with no starter culture (Table 5). Both probiotic white brined cheese samples had a soft fine taste, good flavor and color, and an overall improvement in quality was evident. 
Table 5. Preliminary sensory evaluation of white brined cheese produced with no starter culture, with free L. paracasei SP5 and with immobilized L. paracasei SP5 on trahanas.

\begin{tabular}{ccc}
\hline F & FCF & FITRC \\
\hline $6.92 \pm 0.35^{c}$ & $7.89 \pm 0.29^{\mathrm{b}}$ & $8.12 \pm 0.52^{\mathrm{a}}$ \\
\hline Different superscript letters in a row indicates statistically significant differences (ANOVA, Tukey's HSD multiple
\end{tabular}
range test, $p<0.05) . \mathrm{F}=$ white brined cheese with no starter culture; FFC = white brined cheese produced with free L. paracasei SP5; FITRC $=$ white brined cheese produced with immobilized L. paracasei SP5 on trahanas.

\section{Conclusions}

L. paracasei SP5 was successfully used as a starter culture for white brined cheese production. In addition, its possible probiotic effects could provide a novel functional cheese product to the consumer along with the prebiotic effect of trahanas, which was added as immobilization support. Volatile evaluation revealed cheese products of improved aromatic characteristics by the use of L. paracasei starter culture. Regarding the use of an immobilized biocatalyst, it is of major importance that certain criteria can be fulfilled, i.e., low cost; no cryoprotectants applied during freeze-drying; and enhanced aromatic characteristics of cheese products. Specifically, the freeze drying of the proposed starter culture can ameliorate its commercialization for scale-up purposes, even though white brined cheese production depends on other additional parameters, such as good manufacturing practices. Finally, the traditional production of white brined cheese can be revitalized, in consideration of consumers' concerns regarding safety and health attributes, by the use of novel functional starter cultures that can produce cheese with improved quality characteristics.

Author Contributions: Conceptualization, S.P. and I.M.; methodology, V.G.; software, V.G. and L.B.; validation, S.P. and L.B.; formal analysis, V.G. and I.M.; investigation, S.P., I.M. and V.G.; resources, S.P.; data curation, I.M.; writing-original draft preparation, S.P., I.M. and L.B.; writing-review and editing, S.P.; visualization, I.M.; supervision, S.P.; project administration, S.P.; funding acquisition, S.P. All authors have read and agreed to the published version of the manuscript.

Funding: This research received no external funding.

Institutional Review Board Statement: Not applicable.

Informed Consent Statement: Not applicable.

Conflicts of Interest: The authors declare no conflict of interest.

\section{References}

1. Brown, L.; Caligiuri, S.P.B.; Brown, D.; Pierce, G.N. Clinical trials using functional foods provide unique challenges. J. Funct. Foods 2018, 45, 233-238. [CrossRef]

2. Terpou, A.; Papadaki, A.; Lappa, I.K.; Kachrimanidou, V.; Bosnea, L.A.; Kopsahelis, N. Probiotics in food systems: Significance and emerging strategies towards improved viability and delivery of enhanced beneficial value. Nutrients 2019, 11, 1591. [CrossRef]

3. Rai, A.K.; Pandey, A.; Sahoo, D. Biotechnological potential of yeasts in functional food industry. Trends Food Sci. Technol. 2019, 83, 129-137. [CrossRef]

4. Champagne, C.P.; Gomes da Cruz, A.; Daga, M. Strategies to improve the functionality of probiotics in supplements and foods. Curr. Opin. Food Sci. 2018, 22, 160-166. [CrossRef]

5. Mishra, S.S.; Behera, S.S.; Bari, M.L.; Panda, S.K.; Desobgo, S.C.Z. 5-Microbial bioprocessing of health promoting food supplements. In Microbial Biotechnology in Food and Health; Ray, R.C., Ed.; Academic Press: Cambridge, MA, USA, 2021; pp. 113-141.

6. Santacroce, L.; Inchingolo, F.; Topi, S.; Del Prete, R.; Di Cosola, M.; Charitos, I.A.; Montagnani, M. Potential beneficial role of probiotics on the outcome of COVID-19 patients: An evolving perspective. Diabetes Metab. Syndr. Clin. Res. Rev. 2021, 15, 295-301. [CrossRef] [PubMed]

7. Terpou, A. Ethnic Selected Fermented Foods of Greece. In Fermented Food Products, 1st ed.; Sankaranarayanan, N.A.A., Dhanasekaran, D., Eds.; CRC Press Taylor \& Francis Group: London, UK; New York, NY, USA, 2020; p. 10.

8. Mantzourani, I.; Chondrou, P.; Bontsidis, C.; Karolidou, K.; Terpou, A.; Alexopoulos, A.; Bezirtzoglou, E.; Galanis, A.; Plessas, S. Assessment of the probiotic potential of lactic acid bacteria isolated from kefir grains: Evaluation of adhesion and antiproliferative properties in in vitro experimental systems. Ann. Microbiol. 2019, 69, 751-763. [CrossRef] 
9. Bengoa, A.A.; Iraporda, C.; Acurcio, L.B.; de Cicco Sandes, S.H.; Costa, K.; Moreira Guimarães, G.; Esteves Arantes, R.M.; Neumann, E.; Cantini Nunes, Á.; Nicoli, J.R.; et al. Physicochemical, immunomodulatory and safety aspects of milks fermented with Lactobacillus paracasei isolated from kefir. Food Res. Int. 2019, 123, 48-55. [CrossRef]

10. Cho, Y.-J.; Kim, D.-H.; Jeong, D.; Seo, K.-H.; Jeong, H.S.; Lee, H.G.; Kim, H. Characterization of yeasts isolated from kefir as a probiotic and its synergic interaction with the wine byproduct grape seed flour/extract. LWT 2018, 90, 535-539. [CrossRef]

11. Plessas, S.; Nouska, C.; Karapetsas, A.; Kazakos, S.; Alexopoulos, A.; Mantzourani, I.; Chondrou, P.; Fournomiti, M.; Galanis, A.; Bezirtzoglou, E. Isolation, characterization and evaluation of the probiotic potential of a novel Lactobacillus strain isolated from Feta-type cheese. Food Chem. 2017, 226, 102-108. [CrossRef]

12. Syrokou, M.K.; Paramithiotis, S.; Skandamis, P.N.; Drosinos, E.H.; Bosnea, L.; Mataragas, M. High-quality draft genome sequence data of six Lactiplantibacillus plantarum subsp. argentoratensis strains isolated from various Greek wheat sourdoughs. Data Brief 2021, 107172. [CrossRef]

13. Bozoudi, D.; Torriani, S.; Zdragas, A.; Litopoulou-Tzanetaki, E. Assessment of microbial diversity of the dominant microbiota in fresh and mature PDO Feta cheese made at three mountainous areas of Greece. LWT 2016, 72, 525-533. [CrossRef]

14. Rao, M.; Bast, A.; de Boer, A. Valorized Food Processing By-Products in the EU: Finding the Balance between Safety, Nutrition, and Sustainability. Sustainability 2021, 13, 4428. [CrossRef]

15. Wang, E.S.-T.; Chu, Y.-H. How Social Norms Affect Consumer Intention to Purchase Certified Functional Foods: The Mediating Role of Perceived Effectiveness and Attitude. Foods 2021, 10, 1151. [CrossRef]

16. Lappa, I.K.; Papadaki, A.; Kachrimanidou, V.; Terpou, A.; Koulougliotis, D.; Eriotou, E.; Kopsahelis, N. Cheese whey processing: Integrated biorefinery concepts and emerging food applications. Foods 2019, 8, 347. [CrossRef] [PubMed]

17. Petrova, P.; Ivanov, I.; Tsigoriyna, L.; Valcheva, N.; Vasileva, E.; Parvanova-Mancheva, T.; Arsov, A.; Petrov, K. Traditional Bulgarian Dairy Products: Ethnic Foods with Health Benefits. Microorganisms 2021, 9, 480. [CrossRef]

18. Bosnea, L.A.; Kopsahelis, N.; Kokkali, V.; Terpou, A.; Kanellaki, M. Production of a novel probiotic yogurt by incorporation of L. casei enriched fresh apple pieces, dried raisins and wheat grains. Food Bioprod. Process. 2017, 102, 62-71. [CrossRef]

19. Schoina, V.; Terpou, A.; Angelika-Ioanna, G.; Koutinas, A.; Kanellaki, M.; Bosnea, L. Use of Pistacia terebinthus resin as immobilization support for Lactobacillus casei cells and application in selected dairy products. J. Food Sci. Technol. 2015, 52, 5700-5708. [CrossRef]

20. Terpou, A.; Bosnea, L.; Kanellaki, M.; Plessas, S.; Bekatorou, A.; Bezirtzoglou, E.; Koutinas, A.A. Growth Capacity of a Novel Potential Probiotic Lactobacillus paracasei K5 Strain Incorporated in Industrial White Brined Cheese as an Adjunct Culture. J. Food Sci. 2018, 83, 723-731. [CrossRef]

21. Terpou, A.; Papadaki, A.; Bosnea, L.; Kanellaki, M.; Kopsahelis, N. Novel frozen yogurt production fortified with sea buckthorn berries and probiotics. LWT 2019, 105, 242-249. [CrossRef]

22. Kourkoutas, Y.; Bosnea, L.; Taboukos, S.; Baras, C.; Lambrou, D.; Kanellaki, M. Probiotic Cheese Production Using Lactobacillus casei Cells Immobilized on Fruit Pieces. J. Dairy Sci. 2006, 89, 1439-1451. [CrossRef]

23. Terpou, A.; Gialleli, A.-I.; Bosnea, L.; Kanellaki, M.; Koutinas, A.A.; Castro, G.R. Novel cheese production by incorporation of sea buckthorn berries (Hippophae rhamnoides L.) supported probiotic cells. LWT 2017, 79, 616-624. [CrossRef]

24. Terpou, A.; Mantzourani, I.; Galanis, A.; Kanellaki, M.; Bezirtzoglou, E.; Bekatorou, A.; Koutinas, A.A.; Plessas, S. Employment of 1 . Paracasei $\mathrm{k} 5$ as a novel potentially probiotic freeze-dried starter for feta-type cheese production. Microorganisms $2019,7,3$. [CrossRef]

25. Rolim, F.R.L.; Freitas Neto, O.C.; Oliveira, M.E.G.; Oliveira, C.J.B.; Queiroga, R.C.R.E. Cheeses as food matrixes for probiotics: In vitro and in vivo tests. Trends Food Sci. Technol. 2020, 100, 138-154. [CrossRef]

26. Possas, A.; Bonilla-Luque, O.M.; Valero, A. From Cheese-Making to Consumption: Exploring the Microbial Safety of Cheeses through Predictive Microbiology Models. Foods 2021, 10, 355. [CrossRef] [PubMed]

27. Moatsou, G.; Govaris, A. White brined cheeses: A diachronic exploitation of small ruminants milk in Greece. Small Rumin. Res. 2011, 101, 113-121. [CrossRef]

28. Hayaloglu, A.A. Chapter 39-Cheese Varieties Ripened under Brine. In Cheese, 4th ed.; McSweeney, P.L.H., Fox, P.F., Cotter, P.D., Everett, D.W., Eds.; Academic Press: San Diego, CA, USA, 2017; pp. 997-1040.

29. Schoina, V.; Terpou, A.; Bosnea, L.; Kanellaki, M.; Nigam, P.S. Entrapment of Lactobacillus casei ATCC393 in the viscus matrix of Pistacia terebinthus resin for functional myzithra cheese manufacture. LWT 2018, 89, 441-448. [CrossRef]

30. Rabah, H.; do Carmo, F.L.R.; Carvalho, R.D.d.O.; Cordeiro, B.F.; da Silva, S.H.; Oliveira, E.R.; Lemos, L.; Cara, D.C.; Faria, A.M.C.; Garric, G.; et al. Beneficial Propionibacteria within a Probiotic Emmental Cheese: Impact on Dextran Sodium Sulphate-Induced Colitis in Mice. Microorganisms 2020, 8, 380. [CrossRef] [PubMed]

31. Fusco, V.; Quero, G.M.; Poltronieri, P.; Morea, M.; Baruzzi, F. Autochthonous and Probiotic Lactic Acid Bacteria Employed for Production of "Advanced Traditional Cheeses". Foods 2019, 8, 412. [CrossRef]

32. Margalho, L.P.; Jorge, G.P.; Noleto, D.A.P.; Silva, C.E.; Abreu, J.S.; Piran, M.V.F.; Brocchi, M.; Sant'Ana, A.S. Biopreservation and probiotic potential of a large set of lactic acid bacteria isolated from Brazilian artisanal cheeses: From screening to in product approach. Microbiol. Res. 2021, 242, 126622. [CrossRef]

33. Terzić-Vidojević, A.; Veljović, K.; Tolinački, M.; Živković, M.; Lukić, J.; Lozo, J.; Fira, Đ.; Jovčić, B.; Strahinić, I.; Begović, J.; et al Diversity of non-starter lactic acid bacteria in autochthonous dairy products from Western Balkan Countries-Technological and probiotic properties. Food Res. Int. 2020, 136, 109494. [CrossRef] 
34. Bosnea, L.A.; Moschakis, T.; Nigam, P.S.; Biliaderis, C.G. Growth adaptation of probiotics in biopolymer-based coacervate structures to enhance cell viability. LWT 2017, 77, 282-289. [CrossRef]

35. Terpou, A.; Bekatorou, A.; Bosnea, L.; Kanellaki, M.; Ganatsios, V.; Koutinas, A.A. Wheat bran as prebiotic cell immobilisation carrier for industrial functional Feta-type cheese making: Chemical, microbial and sensory evaluation. Biocatal. Agric. Biotechnol. 2018, 13, 75-83. [CrossRef]

36. Terpou, A.; Gialleli, A.-I.; Bekatorou, A.; Dimitrellou, D.; Ganatsios, V.; Barouni, E.; Koutinas, A.A.; Kanellaki, M. Sour milk production by wheat bran supported probiotic biocatalyst as starter culture. Food Bioprod. Process. 2017, 101, 184-192. [CrossRef]

37. Plessas, S.; Bekatorou, A.; Kanellaki, M.; Psarianos, C.; Koutinas, A. Cells immobilized in a starch-gluten-milk matrix usable for food production. Food Chem. 2005, 89, 175-179. [CrossRef]

38. Marcotuli, I.; Colasuonno, P.; Hsieh, Y.S.Y.; Fincher, G.B.; Gadaleta, A. Non-Starch Polysaccharides in Durum Wheat: A Review. Int. J. Mol. Sci. 2020, 21, 2933. [CrossRef]

39. Kondyli, E.; Pappa, E.C.; Vlachou, A.M. Effect of package type on the composition and volatile compounds of Feta cheese. Small Rumin. Res. 2012, 108, 95-101. [CrossRef]

40. Barouni, E.; Petsi, T.; Kolliopoulos, D.; Vasileiou, D.; Panas, P.; Bekatorou, A.; Kanellaki, M.; Koutinas, A.A. Immobilized rennin in TC/SG composite in cheese production. Food Chem. 2016, 200, 76-82. [CrossRef] [PubMed]

41. Lazárková, Z.; Šopík, T.; Talár, J.; Purevdorj, K.; Salek, R.N.; Buňková, L.; Černíková, M.; Novotný, M.; Pachlová, V.; Němečková, I.; et al. Quality evaluation of white brined cheese stored in cans as affected by the storage temperature and time. Int. Dairy J. 2021, 105105. [CrossRef]

42. Bintsis, T.; Robinson, R.K. A study of the effects of adjunct cultures on the aroma compounds of Feta-type cheese. Food Chem. 2004, 88, 435-441. [CrossRef]

43. Makki, G.M.; Kozak, S.M.; Jencarelli, K.G.; Alcaine, S.D. Evaluation of the efficacy of commercial protective cultures to inhibit mold and yeast in cottage cheese. J. Dairy Sci. 2021, 104, 2709-2718. [CrossRef] [PubMed]

44. Manolopoulou, E.; Sarantinopoulos, P.; Zoidou, E.; Aktypis, A.; Moschopoulou, E.; Kandarakis, I.G.; Anifantakis, E.M. Evolution of microbial populations during traditional Feta cheese manufacture and ripening. Int. J. Food Microbiol. 2003, 82, $153-161$. [CrossRef]

45. Litopoulou-Tzanetaki, E.; Tzanetakis, N. Microbiological study of white-brined cheese made from raw goat milk. Food Microbiol. 1992, 9, 13-19. [CrossRef]

46. Laslo, É.; György, É. Evaluation of the microbiological quality of some dairy products. Acta Univ. Sapientiae Aliment. 2018, 11, 27-44. [CrossRef]

47. Helmy, E.A.; Soliman, S.A.; Abdel-Ghany, T.M.; Ganash, M. Evaluation of potentially probiotic attributes of certain dairy yeast isolated from buffalo sweetened Karish cheese. Heliyon 2019, 5, e01649. [CrossRef]

48. Padilla, B.; Manzanares, P.; Belloch, C. Yeast species and genetic heterogeneity within Debaryomyces hansenii along the ripening process of traditional ewes' and goats' cheeses. Food Microbiol. 2014, 38, 160-166. [CrossRef]

49. Padilla, B.; Belloch, C.; López-Díez, J.J.; Flores, M.; Manzanares, P. Potential impact of dairy yeasts on the typical flavour of traditional ewes' and goats' cheeses. Int. Dairy J. 2014, 35, 122-129. [CrossRef]

50. Al-Nabulsi, A.A.; Osaili, T.M.; Oqdeh, S.B.; Olaimat, A.N.; Jaradat, Z.W.; Ayyash, M.; Holley, R.A. Antagonistic effects of Lactobacillus reuteri against Escherichia coli O157:H7 in white-brined cheese under different storage conditions. J. Dairy Sci. 2021, 104, 2719-2734. [CrossRef] [PubMed]

51. Terpou, A.; Bekatorou, A.; Kanellaki, M.; Koutinas, A.A.; Nigam, P. Enhanced probiotic viability and aromatic profile of yogurts produced using wheat bran (Triticum aestivum) as cell immobilization carrier. Process. Biochem. 2017, 55, 1-10. [CrossRef]

52. Peirotén, Á.; Gaya, P.; Álvarez, I.; Bravo, D.; Landete, J.M. Influence of different lignan compounds on enterolignan production by Bifidobacterium and Lactobacillus strains. Int. J. Food Microbiol. 2019, 289, 17-23. [CrossRef]

53. Randazzo, C.L.; Pitino, I.; De Luca, S.; Scifò, G.O.; Caggia, C. Effect of wild strains used as starter cultures and adjunct cultures on the volatile compounds of the Pecorino Siciliano cheese. Int. J. Food Microbiol. 2008, 122, 269-278. [CrossRef] [PubMed]

54. Michaelidou, A.; Katsiari, M.C.; Kondyli, E.; Voutsinas, L.P.; Alichanidis, E. Effect of a commercial adjunct culture on proteolysis in low-fat Feta-type cheese. Int. Dairy J. 2003, 13, 179-189. [CrossRef]

55. Katsiari, M.C.; Voutsinas, L.P.; Kondyli, E.; Alichanidis, E. Flavour enhancement of low-fat Feta-type cheese using a commercial adjunct culture. Food Chem. 2002, 79, 193-198. [CrossRef] 